\title{
LEAF ANATOMY AND ESSENTIAL OIL PRODUCTION OF Lippia NATIVE SPECIES
}

Ariana Reis Messias Fernandes de Oliveira ${ }^{1}$, Lenaldo Muniz de Oliveira ${ }^{2}$, Joseane Silva Carneiro ${ }^{2}$, Tânia Regina dos Santos Silva ${ }^{2}$, Larissa Correa do Bonfim Costa ${ }^{3}$

${ }^{1}$ Instituto Federal de Educação, Ciência e Tecnologia Baiano - Uruçuca, BA. E-mail: rylreis@gmail.com

${ }^{2}$ Universidade Estadual de Feira de Santana. E-mail: lenaldo.uefs@ gmail.com; carneiro.joseane@ gmail.com; tanialantana@gmail.com

${ }^{3}$ Universidade Estadual de Santa Cruz - Ilhéus, BA. E-mail: larissa@uesc.com

\section{ABSTRACT}

This work aimed to perform a comparative study of leaf anatomy, trichome frequency and essential oil production of some Lippia native species of the semi-arid region of Bahia State, Brazil. Leaf samples were analyzed with light microscopy and scanning electron microscopy to describe the leaf structure and to quantify the trichome frequency. Six types of glandular trichomes were identified: unicellular, bicellular and tetracellular, as well as three types of tectorial trichomes. L. bromleyana presents an ornamented epidermis and no tectorial trichomes on the abaxial surface. L. thymoides has glandular trichomes with irregular contours on both leaf faces, with a higher frequency of tectorial trichomes on the adaxial surface and peltate glandular trichomes on the abaxial surface. L. insignis and L. lasiocalycina are anatomically similar, and present a higher tector trichome frequency on the abaxial surface compared to the others species. L. thymoides and L. insignis stood out for the essential oil production.

Keywords: Lippia spp., essential oil, leaf anatomy

\section{ANATOMIA FOLIAR E PRODUÇÃO DE ÓLEO ESSENCIAL EM ESPÉCIES NATIVAS DE Lippia}

\section{RESUMO}

Esse trabalho objetivou realizar um estudo comparativo sobre anatomia foliar, frequência de tricomas e produção de óleo essencial em espécies do gênero Lippia nativas do semiárido da Bahia, Brasil. Foram identificados seis tipos de tricomas glandulares uni, bi e tetracelular e três tipos de tricomas tectores. L. bromleyana apresenta como diferencial anatômico a presença de epiderme 
ornamentada e ausência de tricomas tectores na face abaxial. L. thymoides possui tricomas glandulares com contornos irregulares em ambas as faces, maior densidade de tricomas tectores na face adaxial e de tricomas glandulares peltados na face abaxial, distinguindo-a das demais. A frequência de tricomas tectores na face abaxial é superior às demais nas espécies $L$. insignis e L. lasiocalycina. As espécies $L$. thymoides e L. insignis se destacaram na produção de óleo essencial.

Palavras-chave: Lippia spp., óleo essencial, anatomia foliar

\section{INTRODUCTION}

The Verbenaceae family comprises 36 genera and 1,000 species (SOUZA; LORENZI, 2005) spread over the subtropical, tropical and temperate regions of America, Africa and India, with the highest natural diversity observed in the subtropical regions of South America (SANDERS, 2001). The Lippia genus includes many aromatic species characterized by essential oils production, which perform different functions such as attracting pollinators or repelling natural enemies of the plant (CASTRO et al., 2005). These essential oils consist of volatile compounds, mostly mono and sesquiterpenes, with notable antimicrobial activity. Many of these species, such as Lippia insignis Moldenke, Lippia thymoides Mart. \& Schauer, Lippia bromleyana Moldenke and Lippia lasiocalycina Cham. are endemic to the Brazilian northeastern semi-arid regions and, despite their importance in folk medicine and their economic potential as a source of herbal medicines, studies on their anatomical, phytochemical or biological activity are scarce or nonexistent.

Trichomes are modified epidermal cells that protrude in the form of hair, scales or papillae (GONÇALVES; LORENZI, 2011). They are basically classified as glandular and non-glandular (tectorial) trichomes, with the glandular ones classified as peltate and capitate (BIASI; DESCHAMPS, 2009). According to Valkama et al. (2003), tectorial trichomes can act as a mechanical barrier against some external factors and the glandular trichomes are involved in chemical protection, by releasing lipophilic substances, such as essential oils. Trichomes frequency can be an indicative of the plant capacity to produce essential oils (DESCHAMPS et al., 2006) and can be used as a parameter in the selection of more productive plants. The types of trichomes, its position on the leaf and its frequency can vary greatly among species. In the Lippia scaberrima species, capitate and peltate trichomes were found on the adaxial and abaxial surfaces of leaves (COMBRINCK et al., 2007). Capitate glandular trichomes were observed on the abaxial surface, while tectorial trichomes can be easily found on both 
leaf surfaces in Ageratum conyzoides (MILLANI et al., 2010.). Martins et al. (2009) described the presence of multicellular tectorial trichomes and capitate and peltate glandular trichomes on the adaxial and abaxial leaf surfaces of Ocimum gratissimum. In Mentha x piperita L. var. piperita, peltate and capitate glandular trichomes were found on both leaf surfaces; however, glandular trichomes were not observed (PEGORADO et al., 2010).

Considering the importance of the secretory structures such as glandular trichomes in aromatic species for the production of essential oils, this study aimed to conduct a comparative study of leaf anatomy, trichomes distribution and essential oil production in Lippia bromleyana, Lippia insignis, Lippia lasiocalycina and Lippia thymoides.

\section{MATERIAL AND METHODS}

\section{Plant material}

Four Lippia species: L. insignis, L. bromleyana and L. thymoides, collected in Morro do Chapéu and L. lasiocalycina collected in Santa Terezinha, both cities of Bahia State, Brazil, were cultivated in the Horto Florestal Experimental Unit at the Universidade Estadual de Feira de Santana (UEFS). The collected plant specimens were sent to the herbarium at the UEFS (HUEFS) where they were properly identified and registered with the numbers: HUEFS 193480 (L. insignis), HUEFS 193481 (L. lasiocalycina) HUEFS 77554 (L. thymoides), and HUEFS 212549 (L. bromleyana).

\section{Light microscopy}

For the leaf anatomy characterization, fully expanded leaves were collected from the third node counted from the apex to the base of the plant's main stem. We used five leaves for each of the four repetitions per species, giving a total of twenty samples per species. Leaf samples were fixed in $70 \%$ alcohol and prepared for anatomical analysis using the Jeffrey's method (MACÊDO, 1997). Free hand cross sections of the leaf were stained with astra blue and safranin (KRAUS; ARDUIM, 1997). Free hand paradermic sections from both leaf surfaces were stained with $1 \%$ safranin for epiderm analysis. Observations were carried out on a Olympus BX51 binocular microscope.

\section{Scanning electron microscopy (SEM)}


We used five leaves for each of the four replications per species, a total of twenty samples per species. Samples from the median region were fixed with $2.5 \%$ glutaraldehyde in $0.1 \mathrm{M}$ sodium cacodylate buffer, pH 6.9 for 24 hours. Following rinsing with the buffer, the material was dehydrated in a graded acetone series, critical point dried and coated with a thin layer of gold. Observations were carried out on a JEOL JSM 6390LV scanning electron microscope.

\section{Essential oil}

The essential oil from leaves and flowers was extracted by hydro-distillation method with a Clevenger apparatus. Fifty grams of dry material was immersed in $1.000 \mathrm{ml}$ of distilled water and boiled for 180 minutes (TELLES et al., 2012). The oil was removed with a Pasteur pipette, stored in glass containers and weighed to calculate the content as g. $\mathrm{g}^{-1}$ of dry matter. After extraction, the essential oil was added with anhydrous sodium sulfate to remove residual water, avoiding loss by hydrolysis during storage. The oil was then conditioned in glass containers with a Pasteur pipette.

\section{Statistical analysis}

For trichome frequency, 40 fields in each of the 20 samples were viewed on the leaves' abaxial and adaxial surfaces using ANATI QUANTI software, the data were subjected to analysis of variance and mean comparison by the Tukey test at a 5\% error probability level, via the SISVAR statistical software (FERREIRA, 2011).

\section{RESULTS AND DISCUSSION}

The leaves of Lippia bromleyana L. insignis, L. lasiocalycina and L. thymoides have some similar anatomical features, such as: uniseriate epidermis; epidermal cells with thin straight anticlinal walls; presence of tectorial and glandular trichomes, with species-specific morphologic variations; hypostomatic leaves; bilayered parenchyma, dorsiventral mesophyll and anomocytic stomata (Figures $1 \mathrm{~A}$ to $1 \mathrm{H})$. The stomata of Lippia bromleyana, L. insignis, L. lasiocalycina and L. thymoides are found at the same level of the epidermis or above the epidermis. 


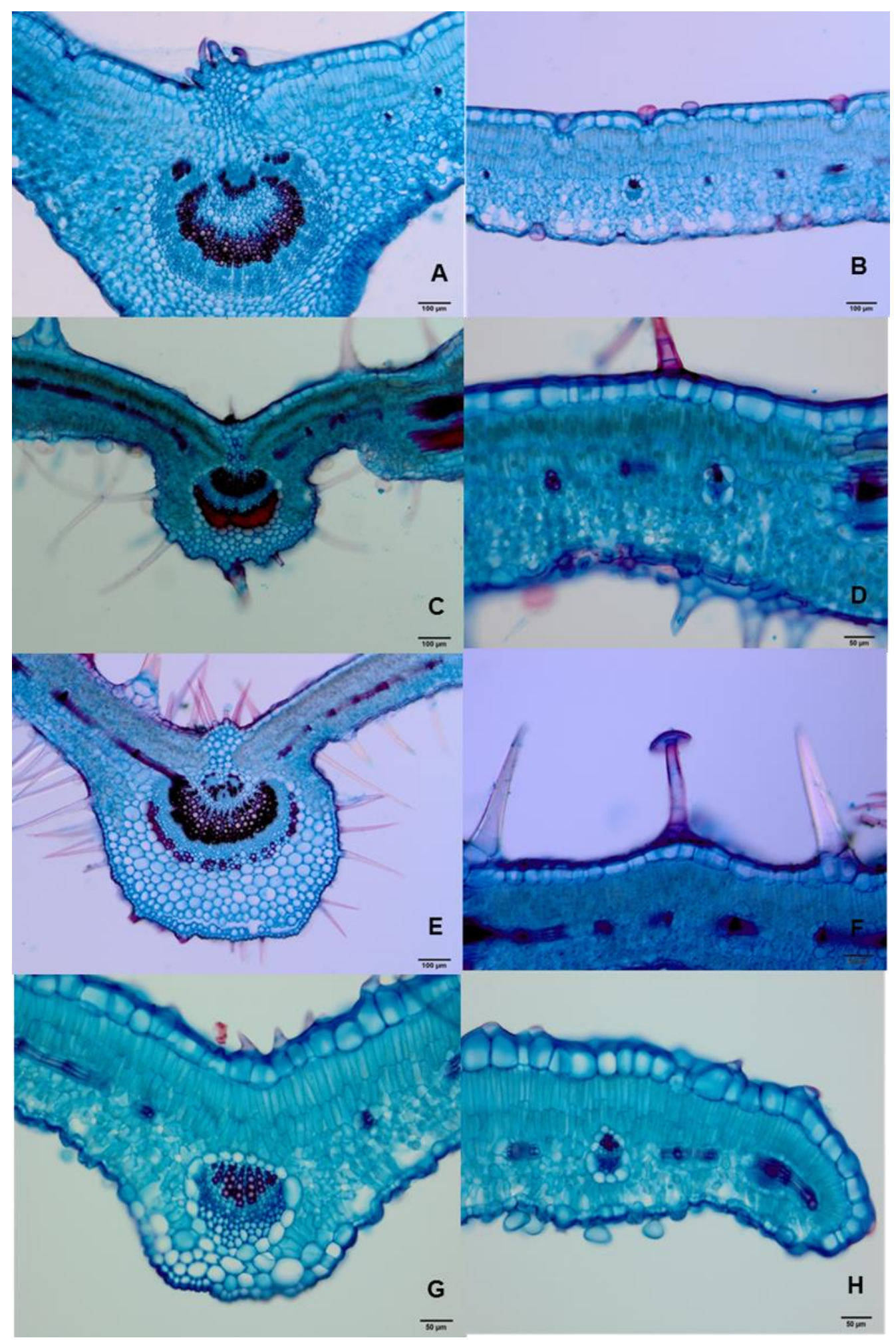

Figure 1. Photomicrograph of leaves cross-section of Lippia bromleyana Moldenke, (A and B), Lippia insignis Moldenke, (C and D), Lippia lasiocalycina Cham. (E and F) and Lippia thymoides Mart. \& Schauer (G and H) cultivated in Feira de Santana, Bahia State, Brazil, 2014. 
In Lippia alba (Mill.), the leaves are characterized by the presence of a simple epidermis, stomata situated on both leaf surfaces, mesophyll formed by uni or bilayered palisade parenchyma, simple tectorial trichomes and three types of glandular trichomes (SANTOS et al., 2004); however, the leaves of two morphotypes of Lippia alba (named as cidreira and melissa) are characterized as amphistomatic,bilayered palisade parenchyma for cidreira and unilayered for melissa (JEZLER et al., 2013). In Lippia sidoides, Nunes et al. (2000) observed the presence of unilayered epidermises with straight to sinuous cell walls, diacytic and anomocytic stomata on both leaf surfaces and glandular and tectorial trichomes distributed throughout the leaf surface. In the studied species, we could only identify anomocytic stomata. Cantino (1990) affirmed that the most frequent stomata found in Lamiaceae and Verbenaceae are the anomocytic and diacytic types.

Glandular and tectorial trichomes are present on both leaf surfaces of all the studied species, in agreement with the descriptions of $L$. alba (JEZLER et al., 2013), L. sidoides (NUNES et al., 2000), $L$. turbinata Griseb, L. fissicalyx Troncoso, L. grisebachiana Mold. Mainly and L. intregrifolia (Griseb.) Hieron. (BASSOLS; GURNI, 2000), with differences in size and morphology. In L. origanoides Kunth and $L$. sidoides Cham Tozin et al. (2015) identified five and four morphotypes glandular trichomes, respectively. Non-glandular and glandular (five) trichomes were identified in L. citriodora H. B. K. (ARGYROPOULOU et al., 2010).

Six types of glandular trichomes were identified; uni, bi and tetracellular, and three types of tectorial trichomes in the studied species (Table 1).

Lippia bromleyana presents an ornamented epidermis, with no tectorial trichomes on the abaxial surface and glandular trichomes only from types I and II are verified (Figure 2A). This characteristic ornamentation sets Lippia bromleyana apart from the other studied species. On the adaxial surface one can find tectorial trichomes with seven to eight basal cells near the leaf base, in the vascular bundle region, and glandular trichomes types I and II (Figure 2B) with a subsessile base in a depression, into the epidermis. 
Table 1. Description and occurrence of tectorial and glandular trichomes in Lippia native species from semi-arid regions of Bahia, Brazil and cultivated at the "Horto Florestal Experimental" Unit of the State University of Feira de Santana (UEFS), Bahia State, Brazil, 2014.

\begin{tabular}{|c|c|c|}
\hline Type & Description & Species \\
\hline & Tectorial trichomes & \\
\hline I & Smooth & L. insignis, L. thymoides \\
\hline II & Smooth with seven to eight cells & L. bromleyana, L. lasiocalycina \\
\hline \multirow[t]{2}{*}{ III } & Verrucous & L. insignis, L. lasiocalycina \\
\hline & Glandular trichome & \\
\hline I & $\begin{array}{l}\text { Tetracellular secretory head, collar cell, short } \\
\text { stalk. }\end{array}$ & L. bromleyana, L. lasiocalycina \\
\hline II & Unicellular Secretory head, collar cell, cell base. & $\begin{array}{l}\text { L. bromleyana, L. insignis, L. lasiocalycina e } L \text {. } \\
\text { thymoides }\end{array}$ \\
\hline III & $\begin{array}{l}\text { Unicellular secretory head, large collar cell, cell } \\
\text { base. }\end{array}$ & L. thymoides \\
\hline IV & $\begin{array}{l}\text { Tetracellular secretory head, collar cell, } \\
\text { bicellular long stalk, cell base. }\end{array}$ & L.lasiocalycina \\
\hline V & $\begin{array}{l}\text { Unicellular Secretory head, collar cell, } \\
\text { unicellular long stalk, cell base. }\end{array}$ & L. insignis e L. lasiocalycina \\
\hline VI & Bicellular secretory head, collar cell, cell base. & L. lasiocalycina \\
\hline
\end{tabular}




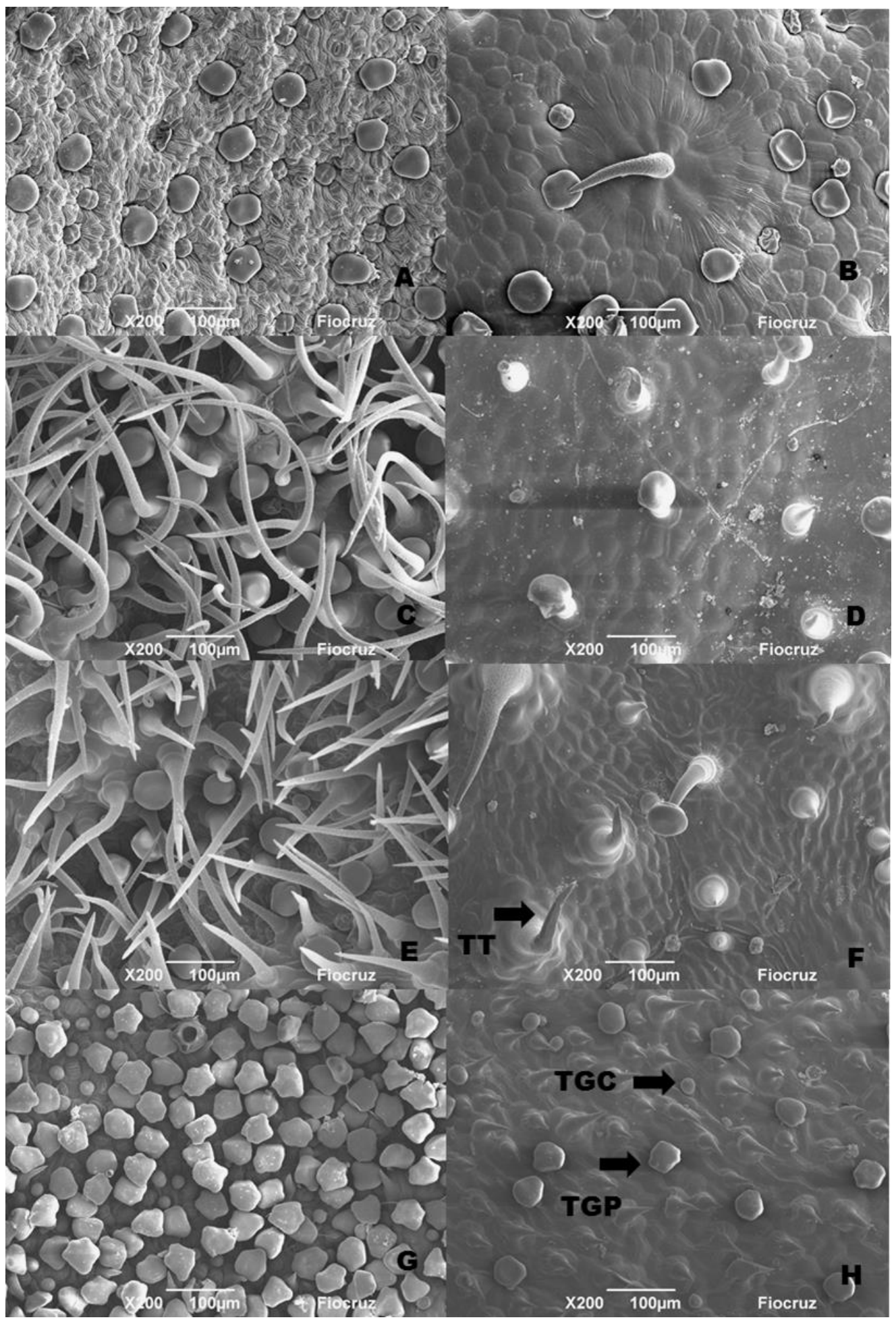

Figure 2. Scanning electron micrograph of the abaxial (A, C, E, and G) and adaxial (B, D, F and H) surfaces of Lippia bromleyana Moldenke (A, B), Lippia insignis Moldenke (C, D), Lippia lasiocalycina Cham. (E, F) and Lippia thymoides Mart. \& Schauer $(\mathrm{G}, \mathrm{H})$ leaves cultivated in Feira de 
Santana, Bahia, Brazil. TT = tector trichomes, $\mathrm{TGC}=$ capitate glandular trichomes $\mathrm{TGP}=$ peltate glandular trichome.

Verrucous tectorial trichomes are found in Lippia insignis, as well as glandular trichomes type II and VI on the abaxial surface (Figure 2C), while the adaxial surface presents smooth epidermis with glandular trichomes type $\mathrm{V}$ and smooth tectorial trichomes smaller than those found on the abaxial surface of the same species (Figure 2D). In Lippia lasiocalycina, a large amount of thinner verrucous tectorial trichomes, similar to those found in species L. insignis are observed, in addition to type I, II, IV and VI glandular trichomes (Figure 2E).

On the adaxial surface, we can observe the presence of smooth tectorial trichomes, with seven to eight cells at the base, and type $\mathrm{V}$ glandular trichomes (Figure 2F). In Lippia thymoides, smooth, glandular trichomes and type II tectorial trichomes with irregular outlines can be found on the abaxial suface (Figure 2G). On the adaxial surface one can also observe smooth short tectorial trichomes (resembling spicules) (Figure 1D), type II and III glandular trichomes and smooth epidermis (Figure $2 \mathrm{H})$. The abundance of tectorial and glandular trichomes on the abaxial surface of Lippia insignis and Lippia lasiocalycina is a differential aspect in relation to the remaining species. In general, glandular and tectorial trichomes are abundant on the abaxial surface of Lippia bromleyana, L. insignis, L. lasiocalycina and L. thymoides leaves (Figure 2). The trichomes frequency is different among the studied species (Table 2). There is no tectorial trichomes on the abaxial surface of L. bromleyana; the tectorial trichome frequency is higher in L. insignis and L. lasiocalycina in comparison to L. thymoides. The highest frequency of tectorial trichomes occurs on the adaxial surface of L. thymoides. According to Werker (2000), tectorial trichomes may act as a mechanical barrier against high luminous intensity and excessive water loss, among other factors, which are characteristic of species from semi-arid regions. Capitate glandular trichomes are present on the abaxial surfaces of the four studied species, but are more frequent in L. thymoides and L. bromleyana. There are no capitate glandular trichomes on the adaxial surface of $L$. thymoides. Peltate glandular trichomes are present on the abaxial surface of all the studied species, but denser in L. thymoides (Table 2). Peltate glandular trichomes are found with the same frequency on the adaxial surface of $L$. bromleyana and $L$. thymoides, but are absent in $L$. lasiocalycina and L. insignis. The trichome frequency can also be related to the leaf development level and to the plant age, as found by Shanker et al. (1999) on Mentha arvensis L. showing that the number of trichomes producing essential oil increased till the leaf reaches maturation, point when it starts to decline. Glandular trichome density was three to four times on the abaxial surface in relation to the 332 
adaxial in populations of L. origanoiodes (TOZIN et al., 2014).

Table 2. Trichome density (trichomes per $\mathrm{mm}^{2}$ ) on the abaxial and adaxial leaf surfaces of Lippia bromleyana Moldenke, Lippia insignis Moldenke, Lippia lasiocalycina Cham.and Lippia thymoides Mart. \& Schauer cultivated in Feira de Santana, Bahia State, Brazil, 2014.

\begin{tabular}{llllll}
\hline & L. bromleyana & L. insignis & L. lasiocalycina & L. thymoides & ${ }^{*} \mathrm{CV}$ \\
\hline TT & ABAXIAL & & \\
CGT & - & $250 \mathrm{a}$ & $226 \mathrm{a}$ & $20 \mathrm{~b}$ & 16,47 \\
PGT & $48 \mathrm{ab}$ & $16 \mathrm{~b}$ & $16 \mathrm{~b}$ & $59 \mathrm{a}$ & 56,07 \\
\hline & $79 \mathrm{~b}$ & $71 \mathrm{~b}$ & $83 \mathrm{~b}$ & $476 \mathrm{a}$ & 20,18 \\
\hline TT & ADAXIAL & & $198 \mathrm{a}$ & 23,13 \\
CGT & 4c & $20 \mathrm{bc}$ & $36 \mathrm{~b}$ & - & 36,98 \\
PGT & $16 \mathrm{a}$ & $12 \mathrm{a}$ & $12 \mathrm{a}$ & $52 \mathrm{a}$ & 31,87 \\
\hline
\end{tabular}

TT=tectorial trichomes CGT=capitate glandular trichomes PGT=peltate glandular trichomes *CV= Coefficient of variation. Means followed by different letters in the line differ by Tukey's test at $5 \%$ probability of error.

In this study, the essential oil content is higher in L. thymoides (1.01\%) and L. insignis (0.99\%) in comparison to L. bromleyana $(0.82 \%)$ and L. lasiocalycina $(0.58 \%)$. This higher essential oil content in L. thymoides may be related to the higher frequency of glandular trichomes found on both leaf surfaces, since they are responsible for the synthesis and storage of the metabolite (BIASI; DESCHAMPS, 2009); however, this relation was not verified in L. insignis. It is possible that other physiological characteristics of these species have a more determinant role in the production of essential oil than the frequency of peltate glandular trichomes. To Deschamps et al. (2006), different factors, such as losses by volatilization and/or catabolism, seem more determinant to the storage of essential oil than trichome density.

\section{CONCLUSIONS}

Frequency and types of trichomes are distinctive characters between the species of Lippia studied; Lippia bromleyana is anatomically distinct by its ornamented epidermis and absence of tectorial trichomes on the abaxial surface; Lippia thymoides has glandular trichomes with irregular 
contours on both sufaces, thereby distinguishing it from the other studied species in addition to a higher frequency of peltate glandular trichomes on the abaxial surface of the leaves; Lippia Thymoides and $L$. insignis presented a higher content of essential oil in leaves and flowers in the conditions in which they were grown.

\section{ACKNOWLEDGMENTS}

The authors would like to thank CAPES for the scholarship, CNPq and FAPESB for financial support.

\section{REFERENCES}

ARGYROPOULOU, $\quad \mathrm{C} ; \quad$ AKOUMIANAKI-IOANNIDOU, A; CHRISTODOULAKIS, $\quad \mathrm{N}$. S; FASSEAS. C. 2010. Leaf anatomy and histochemistry of Lippia citriodora (Verbenaceae) Australian Journal of Botany, Melbourne, v. 58, n. 5, p. 398-409.

BASSOLS, G. B; GURNI, A. A. 2000. Comparative anatomical study on Argentine species of Lippia Known as "Poleo". Pharmaceutical Biology, Abingdon, v. 38, 120-128.

BIASI, L. A; DESCHAMPS, C. 2009. Plantas aromáticas: do cultivo à produção de óleo essencial. $1^{a}$. edição, Curitiba, Layer Studio Gráfico e Editora Ltda,160p.

CANTINO, P. D. 1990. The phylogenetic significance of stomata and trichomes in Labiate and Verbenaceae. Journal of the Arnold Arboretum, Cambridge, v. 71, 323-370.

CASTRO, P. R. C; KLUGUE, R. A; PERES, L. E. P. 2005. Manual de Fisiologia Vegetal (Teoria e Prática). Editora Agronômica Ceres, Piracicaba, 650p.

COMBRINCK, S; PLOOY, G. W. D. U; MCCRINDLE, R.I; BOTHA, B. M. 2007. Morphology and histochemistry of the glandular trichomes of Lippia scaberrima (Verbenaceae). Annals of Botany, Oxford, v. 99, 1111-1119.

DESCHAMPS, C; ZANATTA, J. L; ROSWALKA, L; OLIVEIRA, M. C; BIZZO, H. R; ALQUINI, Y. 2006. Densidade de tricomas glandulares e produção de óleos essenciais em Mentha arvensis L., Mentha x piperita L. e Mentha cf. aquatica L. Ciência e Natura, Santa Maria, v.28, 23-34.

FERREIRA, D. F. 2011. Sisvar: A computer statistical analysis system. Ciência e Agrotecnologia., Lavras, v. 35, 1039-1042.

GONÇALVES, E. G; LORENZI, H. 2011. Morfologia Vegetal. Organografia e dicionário ilustrado de morfologia das plantas vasculares. $2^{\mathrm{a}}$ ed. São Paulo: Instituto Plantarum de Estudos da Flora.430p.

JEZLER, C. N; OLIVEIRA, A. R. M. F; BATISTA, R. S; OLIVEIRA, R. A; SILVA, D. C; COSTA, L. C. B. 2013. Lippia alba morphotypes cidreira and melissa exhibit significant differences in leaf characteristics and essential oil profile. Revista Brasileira de Farmacognosia, Curitiba, v. 23, 217-223.

KRAUS, J. E; ARDUIN, M. 1997. Manual básico de métodos em morfologia vegetal. EDUR, Rio de Janeiro. 198p.

MACÊDO, N. A. 1997. Manual de técnicas em histologia vegetal. Universidade Estadual de Feira de Santana, Feira de Santana. 96p. 
MARTINS, J. R; ALVARENGA, A. A; CASTRO, E. M; SILVA, A. P. O; OLIVEIRA, C; ALVES, E. 2009. Anatomia foliar de plantas de alfavaca-cravo cultivadas sob malhas coloridas. Ciência Rural, Santa Maria, v. 39, 82-87.

MILlANI, A. A; ROSSATTO, D. R; RUBIN FILHO, C. J; KOLB, R. M. 2010. Análise de crescimento e anatomia foliar da planta medicinal Ageratum conyzoides L. (Asteraceae) cultivada em diferentes substratos. Revista Brasileira de Plantas Medicinais, Botucatu, v. 12, 127-134.

NUNES, R. S; XAVIER, H. S; ROLIM NETO, P. J; SANTANA, D. P; ALBUQUERQUE, U. P. 2000. Padronização Botânica de Lippia sidoides Cham. (Verbenaceae). Acta Farmacêutica Bonaerense, Buenos Aires, v. 19, 115-118, 2000.

PEGORADO, R. L; FALKENBERG, M. B; VOLTOLINI, C. H; SANTOS, M; PAUlilO, M. T. S. 2010. Produção de óleos essenciais em plantas de Mentha x piperita L. var. piperita (Lamiaceae) submetidas a diferentes níveis de luz e nutrição do substrato. Revista Brasileira de Botânica, São Paulo, v. 33, 631-637.

SANDERS, R. W. 2001. The genera of Verbenaceae in the Southeastern United State. Harvard Papers in Botany, Cambridge, v. 5, 303-358.

SANTOS, M. R. A; INNECCO, R; SOARES, A. A. 2004. Caracterização anatômica das estruturas secretoras e produção de óleo essencial de Lippia alba (Mill.) N.E. Br. Em função do horário de colheita nas estações seca e chuvosa. Revista Ciência Agronômica, Fortaleza, v. 35, 377- 83.

SHANKER, S; AJAYAKUMAR, P. V; KUMAR, S; SANGWAN, R. S. 1999. Essential oil gland number and ultrastructure during ontogeny. Biologia Plantarum, Prague, v. 42, p. 379-387.

SOUZA, V. C; LORENZI, H. 2005. Botânica sistemática - guia ilustrado para identificação das famílias de angiospermas da flora brasileira baseado em APG II. São Paulo, Instituto Plantatrum. 640p.

TELES, S; PEREIRA, J. A; SANTOS, C. H. B; MENEZES, R. V; MALHEIRO, R; LUCCHESE, A. M; SILVA, F. 2012. Geographical origin and drying methodology may affect the essential oil. Industrial Crops and Products, Amsterdã, v. 37, p. 247-252.

TOZIN, L. R. S; MARQUES, M. O. M; RODRIGUES, T. M. 2015. Glandular trichome density and essential oil composition in leaves and inflorescences of Lippia origanoides Kunth (Verbenaceae) in the Brazilian Cerrado. Anais da Academia de Ciências, Rio de Janeiro, v. 87, n. 2, p. 943 953.

TOZIN, L. R. S. CARVALHO, S. F; MACHADO, S. R; RODRIGUES, T. M. 2015. Glandular trichome diversity on leaves of Lippia origanoides and Lippia stachyoides (Verbenaceae): morphology, histochemistry, and ultrastructure. Botany, Ottawa, v. 93, n. 5, p. 297-306, 2015.

VALKAMA, E; SALMINEN, J. P; KORICHEVA, J; PIHLAJA, K. 2003. Comparative analysis of leaves trichome structure and composition of epicuticular flavonoids in Finnish Birch species. Annais of Botany, Oxford, v. 91, p. 643- 655, 2003.

WERKER, E. 2000. Trichome diversity and development. In: HALLAHAN, D.L.; GRAY, J.C. Plant Trichomes. London: Academic, p.1-30. 